\title{
Principles and Values as Essential Elements that Shape Social Policy
}

\author{
Stefanos Koffas \\ Institute for Continuing Education and Continuing Education, Katholische Stiftungsfachhochschule München, Germany
}

Copyright $(2017$ by authors, all rights reserved. Authors agree that this article remains permanently open access under the terms of the Creative Commons Attribution License 4.0 International License

\begin{abstract}
Dealing with social policy as a meaning, but also as an applied practice in social sector interventions, presupposes knowledge of the basic principles and values on which the philosophy of its existence and operation is based. Besides the historical reasons of the socioeconomic environment behind the development of social policy, the guiding principles and social values that govern it are also very important. More specifically, the anthropo-philosophical and Christian principles - other than being structural elements of human behaviour - serve as collective values as well as guiding principles for the harmonious working together of social life and state intervention when social policy is applied at the macro level. In any case, the effectiveness of each decision to intervene, and the accomplishment of its objectives, is highly dependent on its ideological background, which exists in relation to the current social values. The existence of social equality and justice, the reduction of social problems, as well as the reallocation of goods and services, presuppose the smooth operation of the value system and the preservation of its fidelity. The value system encompasses the local government and normative/regulatory conformity as foundations of the systemic operation of society's subsystems; in regard to the value system solidarity, subsidiarity and personal responsibility constitute the foundations of human behaviour. The presentation of the principles and value system on which the operation of social policy is based within the framework of the EU are the basic prerequisites for comprehending its operation. Moreover, this step as the new challenge of human reaction against to the monetarism of the economy. It is obvious that together with the neoliberal concept a very close cooperation with the human values is necessary.
\end{abstract}

Keywords Social Policy, Principles, Values, Solidarity, Subsidiarity, Personal Responsibility

\section{Introduction: Principles and Values}

The relationship between principles and values is very close and interrelated. It may be described as a reciprocal relationship since "social principles constitute expressions of the good from an ethical, spiritual or material perspective, which the authorities intend to pursue, by projecting them as reference points for the appropriate construction and the orderly administration of social life. However, values also demand the practice of fundamental principles of social life and personal ethical behaviour that correspond to the same values" [1, p.168]

Social values as well as principles are related to dignity in life and social normality in human relationships. Their practical importance is that they are the means to maintain a more humane social existence within the context of collective coexistence and its continuation. That is why social values are considered inevitable reference points by those in charge of public affairs who are called to decide upon essential reforms in economic, political, cultural and technological structures and the necessary changes in institutions. As the various choices of man, through time, have shown, respect for the implementation of social principles and values confirms their need for peaceful and prosperous living conditions. In contrast, their distortion and disregard negates to a great extent the course of social normality and is associated with conditions of social regression.

\subsection{Principles}

From a sociological point of view, a principle is "defined [as] any basic rule which sets the groundwork, regulates personal and social behaviour and is commonly acceptable" [2]. The shaping of social policy is closely related to the overall principles, namely any valuable good, mainly spiritual, that functions as a guiding factor in the life of a person or is recognized as such by the social group. And this is so because according to their etymological meaning "principles are the operational projections and points of reference of the social system" [2], which govern its operation and consequently that of its parts as well, including social policy. Furthermore, principles function as models when deciding the type of intervention in social policy, i.e. 
welfare, insurance or security ${ }^{1}$ [3, p.42], its model, whether residual or institutional/redistributive ${ }^{2}$ [4, p.24], the intervention method in cooperation with all institutions, agencies and mechanisms whose main goal is to redistribute goods and services. Depending on their orientation, as expressions of the whole, they form the base of political ideologies, with different and often contrasting approaches, and with significant effect on the managerial and administrative function of each country's systems [5, p.88]. The neoliberal ideology adheres as much as possible to the unimpeded operation of the free market economy [6]; the principles of individualism and competition prevail, thereby defining the way the residual model works. In contrast, the ideological approach of the institutional/redistributive model aims for broader coverage of citizens' needs with widespread state intervention [6], by putting forward social welfare and subsidiarity for social cohesion as principles of its operation.

Irrespective of the ideological orientation of each intervention policy and its synergy with the economic model, the basic social principles endure through time. It is anticipated that their implementation will eradicate all prejudice, establish full equality between the two genders, eradicate extremes in poverty and affluence, provide universal education, promote high-level health and welfare and promote a viable balance between nature and technology. When one considers how aptly those principles are applied in social actions and concerns/problems that disconcert people in every era -from gender relationships to social justice- and which gave rise to the most dynamic movements of the $20^{\text {th }}$ century, their importance, even in the intervention method through the implementation of social policy, becomes self-evident.

\subsection{Values}

Values are defined as beliefs which incorporate clear or implicit conceptions of the desirable, i.e. the deeper desires of a society, determine the choice of means and model of action and play a central role in the belief system of individuals and groups [7]. Indeed, it is "everything that individuals or the society recognize as beneficial, good from an ethical, spiritual or material perspective, which is used as a rule of thumb for actions or becomes the object of a person's pursuits" [2]. Values serve as beacons or guidelines for us and others, as well as for the selection of ideal behaviours in life, incorporating a tint of "should, ought" [8, 9, 10].

1 According to Iatridis, there are three types of social policy: social welfare, whereby the state unilaterally provides benefits to certain people or groups who are in need of assistance, social insurance by reciprocating benefits against contributions by citizens, and social security, broader than social insurance, which insures the individual against certain risks [3].

2 The residual model is based on the perception that the state intervenes only in case the family, the community and other informal solidarity networks, as well as the free market mechanism are unable to cover the needs of people or certain social groups. The institutional/redistributive model of social policy focuses on the development of institutions and mechanisms of universal coverage and prevention of social problems [4].
All human societies create values, because that is how they regulate the attitudes and behaviour of people and constitute a necessity for how they think and act both individually and collectively [11, p.29]. Since they have a functional connection to the structure and operation of social systems, as well as life attitudes, they are related to more general social issues, such as belief in a fair world, altruism as well as to decisions pertaining to the development of social interventions [8] through social planning and social policy. Furthermore, each society has its own value system, which is shaped and passed on through formal and/or informal processes of social learning and is related to tradition, customs, way of communication, introvert or extrovert behaviour, meritocracy, transparency etc. [5, p.91]. Because of the existence of such differentiations the values of each society are also rated differently. Therefore, some values are on the upper tiers of this hierarchy and others are not. For example, material values are more suitable to certain social policy models and their implementation as is the case of the prioritization of material values in the residual model. In contrast, countries and societies orientated towards spiritual values, such as greater degree of justice in the allocation of available resources, they tend towards variations of the institutional model of social policy.

\section{Principles and Values as Basic Elements of Social Policy}

\subsection{Solidarity}

The concept of solidarity, at least in the form it took in Europe over the last two centuries, was never an exact translation of the Greek term. Today, the word that is widely used in other languages, come from the Latin "solidum" which means "the whole" or "the totality", giving rise to the words solidarity (in English), solidarité (in French) etc. Hence, it is obvious that the Greek translation of the foreign term as "allileggii" ( $\alpha \lambda \lambda \eta \lambda \varepsilon \gamma \gamma \nu$ in) which is based on the Greek

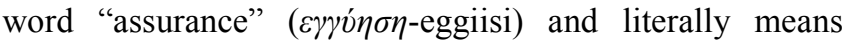
"mutual assurance", inspires the development of a social contract, without referring specifically to a collective attitude or joint action [12].

Solidarity is a concept significantly influenced by the social didache of Christian teaching and is used to describe mutual support among people [13, p.205] as a principle of the actual implementation of the charitable life of Christians, but also of social harmony in line with the teachings of the Fathers. However, besides the Christian teaching of people supporting each other, practically solidarity spread wider also as a result of the collective struggles of the 19th century labour movement, in the sense of a joint effort and mutual support among workers. "The most widespread simple definition of the principle of solidarity is the one that describes the implementation process of solidarity as one for all and all for one" $[14$, p.101]. In every day practice this 
implies the mutual cohesiveness among people, but also among social groups (family, unions, community) in the sense of mutual moral responsibility and dealing with life incidents.

The principle of solidarity in social policy is practically stating the need for the existence of assistance/support in different levels. From the one side at the planning and decision making levels, and from the other side at the functional and system-efficiency levels. What it means is that common interests which exist as expressions of the common feeling of belonging to the same society, but also as a product of conforming to the same needs, should be regulated on the basis of mutuality for covering the needs of society as a whole $[15, \mathrm{p} .62]$. Therefore, the subjects and systems/services ought to be based on practices of mutual interreaction in order to attain their objective goals. Characteristic examples of the application of the principle of solidarity in social policy are the national insurance and welfare systems of countries which are structured on systems of transgenerational reciprocity [16, p.171]. In those cases individual contributions to the appropriate agencies are based on the principle of collective solidarity whereby "individual contributions may vary depending on the income level; however, the benefits provided by the state, especially those related to non-income criteria, are the same, so that despite the contribution levels social reallocation can occur towards those in greater need and also in its majority from those younger in age towards those who are older" [17, p.47] Indeed, the way in which those systems operate should be such that their long-term viability is ensured, thereby maintaining the relationship of solidarity/informal contract of reciprocity between generations $[18, \mathrm{p} .30]$.

In the European Union (EU), as a system organized and structured in a specific way, the value of solidarity is incorporated at various levels, such as solidarity among member states, solidarity towards its society, as well as the solidarity of its citizens. In the context of the legal-political approach, solidarity in the EU includes types of behaviour which may become useful or supportive to other people or organizations and are based on or are associated with a form of obligation or commitment for the safeguard of certain values. More specifically, in the framework of the EU solidarity means an obligation to: a) provide someone help ${ }^{3}$ in order to promote a common goal, b) which is based on the recognition of equality among the parties involved, without any financial or other asymmetry, and finally c) the mutuality of obligations $[19, \mathrm{p} .1]$

\subsection{Subsidiarity}

The word subsidiarity means to assist, support someone in

\footnotetext{
${ }^{3}$ In order to provide support in the context of solidarity, it is possible to impose or demand prerequisites (conditionality). The economic crisis and its handling both by the EU and each of its member states are tangible examples of doubt, skepticism and/or reconsideration of the content and meaning of solidarity at the European level [19].
}

a state of need who requires help [20, p.508]. According to Brück, the word acquired its semantic form with the social encyclical of Pope Pius XL in the year 1931 (par. 79). It describes a fundamental operational principle of society in regard to self-determination, taking responsibility and developing personal skills by each individual member [17, p.44] in the day-to-day, but also long-term effort to develop one's life. According to the principle of subsidiarity no one should be deprived of the opportunity to take initiatives, to try and use his own powers to achieve things by ceding the responsibility of such tasks to society, as it would conflict with the sense of justice and equal participation. Instead the institutional mechanisms of society should intervene only in cases where the capabilities of an individual or small group (community, family) are not sufficient to see to and cover their existing needs on their own. It is only then that the institutional intervention of society's instruments acquires real meaning and becomes subsidiarity in practice [17, p.64]. This is so because each overarching local or state authority should respect and allow the use of resources available to the underlying groupings, without inhibiting their ability to develop, utilize resources they possess or draining them.

According to Brück this explanation of how the principle of subsidiarity is applied means that a hierarchy is followed by participants of societal activities, where the expectation of help should follow a certain order. Self-help ranks first in preference, whereby each person using the powers available to him tries to address his needs. If for any reason this cannot be achieved, those efforts should be supplemented by support from the immediate social web, i.e. informal care networks such as family, friends, neighbours, which should be active and available. If those help structures fail and the need remains, then higher in rank mechanisms, such as local government services, should assist and eventually be followed by state services. In order to avoid any misunderstanding in regard to the principle of subsidiarity, Brück further explains that subsidiarity does not guarantee in advance the provision of help by higher tiers, but only when the individual has used up his own resources, third parties have available resources, as well as certain conditions are fulfilled [17,p.44].

It should be noted that the individual perspective of responsibility and the social perspective of the development of material prerequisites for independent actions, which already co-exist in the principle of subsidiarity, are indeed discrete in the order they are used, yet cannot be dissociated as totally independent. In practice and depending on the model of social policy applied its elements are related more to either the neo-liberal model or the welfare state. In the case of the neo-liberal model, the individual should assume as much responsibility as possible using own means and adjust/adapt his behaviour accordingly. As the various needs constitute economic goods, the individual alone has the autonomous role to cover/secure them. Based on the terms of the market economy, it is expected that the behaviour of individuals should be more oriented towards prevention in 
order to achieve greater use of own resources which are located in the lowest tiers of social structures [21, p.3]. Consequently, this requires less participation of the overarching mechanisms and resources of the state, thus resulting in lower state intervention.

When the institutional/redistributive model is applied and a national redistribution system of benefits is also in place, even though the state is obligated to provide the appropriate services, the level of help may differ according to the resources available to the state $[22,23]$. This is where the significance of the individual's participation is pinpointed who despite being the recipient of state services is in no way responsibility-free. This is so because even in the context of the institutional model, subsidiarity becomes available by utilizing the entirety of resources, both state and private. Hence, the ability to offer help depends to a great extent on the co-responsibility shown by each person while using the resources available, but also on the extent of his ability to recognize that they are finite and should be used rationally. All things considered, it depends greatly on the prevailing cultural model in which he lives, the influence of which he receives and the aspects of cultural elements he accepts and adheres to in his life. Ideally, both in the case of positive cultural influence and of the individual's conscious co-responsibility in issues of assistance and management of resources, state intervention is as little as possible [21, p.4].

The principle of subsidiarity, as applied within the framework of the EU, functions as a criterion regulating the exercise of non-exclusive competencies of the $\mathrm{EU}^{4}$ [24]. It precludes the intervention of the $\mathrm{EU}$ when an issue can be efficiently resolved by member states at a central, regional or local level and authorizes the EU to exercise its authority when member states are unable to achieve, in a sufficient manner, the objectives of a proposed action and the action at the EU level may introduce added value. The overall importance and objective of the principle of subsidiarity is to secure a certain degree of independence for an authority lower in the hierarchy against one that is higher. Therefore, it concerns the allocation of competencies among the various authority levels, a principle which constitutes the basis of states with federal structure. In sectors that do not fall under the exclusive jurisdiction of the European Union, the principle of subsidiarity aims to defend the ability of member states to make decisions and act, and provides legitimacy to

4 The Treaty of Lisbon categorizes the competencies of the Union in three categories: exclusive competencies, shared competencies and complementary competencies. The first category refers to competencies the handling and processing of which reside exclusively with member states. The second category includes competencies that are shared between states and the EU according to specific terms of cooperation. The third category is the provision of assistance to member states by the EU when it is deemed necessary and when requested. Within the context of the non-exclusive competencies of the EU, the principle of subsidiarity, which is included in the Treaty of the European Union, presupposes that three conditions are met: a) it does not involve a sector which falls under the exclusive competence of the Union (non-exclusive competence), b) the objectives of the proposed action are impossible to sufficiently achieve by member states (need), c) the action may by reason of scale and effect be better achieved by an intervention of the Union (added value) [24] the interventions of the Union if the objectives of an action cannot be sufficiently achieved by the member states but may be better achieved at the Union level "by reason of the scale and effects of the proposed action" [24].

\subsection{The Principle of Personal Responsibility}

The concept of responsibility means "the obligation of a person to complete a task and to be held liable for it, bearing the consequences for the poor management of the task or for breaching a moral obligation" [20, p.540]. Personal responsibility belongs to the main principles of Christian social teachings and in accordance to its meaning is closely related to the principle of subsidiarity and the solidarity behaviour. Each person has indeed the right to freely develop his personal skills, but at the same time he is responsible and liable for each of his actions within the context of social normality [15, p.57]. This is so because social coexistence becomes possible through both personal but also collective responsibility. No system can function on its own, just as no society can rely on individual actions alone. People participate in actions collectively to produce results, have ambitions and desire for progress and development; they are people who bear personal responsibility for their actions, their manner of participation, but also for their results.

The role of social policy is to create the conditions under which each person can develop his potential to grow, but also be able to help himself when needed. Therefore state interventions should not inhibit personal liberty, but should allow people to take initiatives and be responsible for their outcome. Taking personal responsibility presupposes that each person at his own initiative should be able a) to want to take action, i.e. act in an objective or subjective manner or b) be able to do so: [15, p.57].

Frequently though, even the mention of personal liability is enough to cause upheaval; perhaps because strong as well as difficult feelings often lurk behind this meaning. This is the result of super-competitive societies where the meaning of personal responsibility is inextricably linked to control, efficiency, taking the blame or in the worst case to an impending sanction. Consequently, it should cause no surprise that taking responsibility has become a source of stress in various aspects of one's life - either private or professional. Most people's usual reaction is to abdicate any responsibility that might even correspond to them and instead seek another person or social group to hold liable. However, this attitude is not objective or just in regard to the context in which they exist and lacks in contribution towards society as a whole. Still, it is the tangible reality of capitalist societies especially those with sanctimonious projections and doubts for the value system. Furthermore, it constitutes a personal choice within the context of a materialistic way of life, but also of individualism ${ }^{5}$ [25], where the conviction

5 The term individualism in social theory was used by the followers of French philosopher and economist Claude Henri de Rouvroy de Saint-Simon. According to this ideology the individual is responsible for the conditions of his life [25]. 
that each person develops his own judgement and behaviour, and is considered responsible for his life prevails [21, p.26].

Based on the theory individualism, states that apply neo-liberal model forms of social policy transfer a significant part of the responsibility to each individual and their behaviour. That is because the actions/decisions of people are mostly perceived/measured in regard to their outcome, as economic figures, just like everything else where each person separately has an autonomous role and is liable for his potential success or failure. Within the context of models that provide comprehensive services outside the market framework and on a need basis, social policy is perceived as a major social institution, which is based on the collective management of responsibility where the outcome concerns all and depends to a significant extent on collective actions. As such those models are partly based on theories relating to the multiple effects of social change through solidarity actions and synergy with the economic system and partly on the principle of social equality [26].

Personal responsibility, in mixed or pluralistic ${ }^{6}[27]$ models, is delimited by the relationship of three important social institutions: the state, the market and the family. According to this approach, social policy places more emphasis on the interplay of the state, the market and the family and tries to utilize the already existing relationship between the private sector and the households, while at the same time reducing the extent of state benefits. The outcome of this partnership is the formation of a public space for the expression of personal but also collective responsibility, consisting of non-governmental and voluntary organizations, citizen initiative groups and social movements. What is important in this formation is that any change in the relationship between any of the participants influences the entire mix and at the same time is affected by changes in the degree of responsibility assumed [28, p.109] [29, p.213].

\subsection{Social Self-Government}

Social self-government means "I make my own decisions on issues pertaining to local matters/needs. I handle the administrative arrangements for anything that concerns me without depending on the central authority" [20, p.215] whenever possible. This, together with the classical principles of taking personal responsibility and collectivity on issues of collective action and joint decision making, make up the requirements for the operation of social life. In the context of social reality "social self-government means that in the framework of the legally instituted obligations of the society and the state, for covering material needs, and at the same time the practice of personal responsibility, those

6 In the pluralistic model, state intervention changes just like the extent and scope of the intervention. Without yielding the primary regulatory role and the ability to enforce control, it limits the extent of state benefits and places more emphasis on support and partnership with the private sector. The objective is to restrain spending, since it considers that partnership with various agencies ensures better benefits at a lower cost and more rational allocation of economic and human resources [27]. obligations should be fulfilled by adhering to subsidiarity and solidarity behaviour" [31, p.424].

The hierarchy of actions from the lower to the higher administrative levels should be followed, while at the same time utilizing collectivity and assistance. In this way, all parties involved at the various levels operate, not only within the boundaries of competence they have or is awarded to them but also their relationships are bound by cooperation and togetherness. Therefore, in accordance with social self-government, the objectives and obligations of social policy should not remain centralized solely at the state level, but smaller decentralized social structures of local government may just as well undertake part of them. Thus, they ensure the efficient execution of implementation measures of social policy at the local level and at the same time act as participants and social partners contributing to the decongestion of central structures and services.

The operation of social self-government enables addressing social risks in ways and by means in close proximity to the citizens. As causal factors are more easily identifiable by the people who themselves experience a difficult situation, the required actions and the availability of the necessary resources are easier to coordinate by in situ actions thereby minimizing response times. Furthermore, political decisions and other intervention measures are acted upon faster in comparison to those at higher levels, since the encumbrance of bureaucracy is avoided, but also because they are closer to people's expectations and the particularities of each region. Those are field actions, which take place in the context of daily life and vary in form: needs assessment and taking the required action, interventions in situations of crisis, coordination interventions and/or developmental initiatives [31, p.98]. The existence of powerful self-government entities at all levels (individual, group, collective) with specific duties and responsibilities results in the mobilization of forces by these entities, whether at local or state level, for better development, coordination, planning and eventually implementation of policies and social policy progammes. State guidelines on issues of social policy become more efficient when local structures and local government mechanisms are involved; they limit potential hindrances and difficulties due to fewer bureaucratic procedures and ensure better quality in the services they provide.

\subsection{Regulatory Conformity}

Regulatory conformity is the behaviour a social group expects from an individual belonging to it. According to Robert Merton conformity is one of the five major modes of adaptation to one's social environment. The other four are innovation, ritualism, retreatism and rebellion. In conformity, the individual accepts the culturally defined goals as well as the socially defined means that are made available to him in order to achieve them $[11, \mathrm{p} .251)$. 
In the post-industrial modern society of digital information, conformity is structured upon different subsystems which affect the ultimate form it takes and made apparent by the descriptive elements of social reality. As the capitalist model has prevailed in the organization of production and also in the operation of the free market economy, the economic system now enjoys a higher value in people's minds compared to other subsystems both at the individual and general social level [29, p.22].

Consequently, it is not by chance that the pursuit of amassing material goods and leading a selfish way of life have prevailed in regulating people's lives, instead of the moral principles and rules of behaviour. Those elements affect negatively not only personal behaviour, but function, even more so, as models of consumerism in today's society by defining to a significant extent the way its members operate and their orientation. The shift towards well-being and welfare by any means, even consciously at the expense of other people, have disrupted social justice and are testing social cohesion through the materialistic polarization among social strata. "In the 'new civilization' of seizing and of provocative consumption ... without asceticism ${ }^{7}$ (economists even call it austerity for some classes!), the person loses every vision of his future and is transformed into a predatory beast of the present" [33, p.34], distanced from any notion of love for his neighbour or concern for the common good [34]

On the other hand and as the centuries-long history of human co-existence has proven, the creation of social order is based on the constant side-by-side operation of all subsystems and values, whether material or immaterial. Efficient cooperation and coordination of both the economic and social aspects are prerequisites, especially for the operation of social policy, but also so is the importance attached to the value system as a regulator of human and social relationships through relations of interdependence. It is a delicate relationship of balanced allocation of duties, responsibilities, priorities, coordination and sequence, which constitutes the regulatory factor in regard to the expression of different forms of social order and social justice that countries choose to follow: for example through redistributive, compensatory, supportive or reciprocal measures according to the economic and social policy models they follow, but also according to the particular characteristics and prevailing conditions. "The way the economy and market factors are linked with the other defining elements, i.e. the family, informal networks and the activities of the subjects, has a direct link and

7 The ascetic attitude both as a life experience and practice that permeates Greek culture and tradition, is expressed by the Fathers of the Church also in regard to the philosophy behind the operation of social welfare. "Providing and caring for the needy is the material outcome of the transformation of individualities into persons who participate in life, into members of a body of life. 'And whether one member suffers, all the members suffer with it' (1 Corinthians 12:26). Asceticism for the Church signifies the expression of love and not the effort to combat evil or improve one's living conditions" [32, p.125] interconnection with the provision of social care services, insurance and protection; they take different forms in different countries, possibly with similar formal safeguards, but not necessarily actual legislative/institutional ones. The vital difference is the extent to which the legislative framework is implemented (in its totality or at will), the means that are used (legitimate or illegitimate), by whom (institutionalized agencies or intermediaries) and how (transactional or intertwined interests)" [35, p.202].

The stability of social order is the outcome of perpetual regulation from a philosophical point of view, a balance in order not to jeopardize its overall ability to function due to internal inequalities and uneven distributions of its constituting parts. The perceptions of the last decades have brought about a disturbance in the balance of social reality and even more so in social relationships. Namely, society as well as human and social relationships are determined by the economic reality, are closely influenced by it and consequently are directly dependant on its course and requirements. Following the same logic, social policy is presented as dependant on economic policy, since that is where the necessary resources for its existence come from [30, p.424], while overlooking their solidarity correlation and co-subsidiarity. However both dimensions, i.e. the economic and social aspects, matter and values, are subsystems of social order and logically they should be in the same plane as being of equal value in the context of an inter-complementing synergy. It is the duty of the state to intervene so that the subsystems of society are able to fulfill the duties that warrant their existence [14, p.103] in order for a harmonious and conflict-free co-existence among the subjects of society to be possible.

\section{Conclusions}

Over the last years the ideology of capitalist, neo-liberal approach through its economic dimension has influenced people's life attitudes, especially in regard to their behaviour as individuals/units, neglecting their status as individuals/members of social society. The subjects' concentration on material amassment creates serious problems in the collective structure of social co-existence. As Stasinopoulou correctly underlines "we are living in times that individualism prevails, it is 'I' instead of 'we'. A pagan era ... where objects are given fictional qualities of social relationships, while human relationships are 'objectified"" ${ }^{\prime}[4, \mathrm{p} .112]$

\footnotetext{
8 As John Holloway explains: "In capitalism the relationship between people and objects, between subject and object is inverted. ... Objects (money, capital, machinery) become the subjects of society while the people (workers) become the objects. Social relationships are not only apparently but also actually relationships between objects (between money and the state, between your money and mine), while people are deprived of their sociable nature, are transformed into 'units', the essential supplement of the trade transaction [36, p.116].
} 
It is generally recognized that the dominant consumerist model for attaining personal well-being has long ago exhausted its capabilities of using the state monetarist benefit policy as a means to intervene and restore distortions of economic inequalities. The current demand is to remove any pathogenesis both from passive state policies, as well as the prevalent but also fictitious in essence, obsessive contrast of individual-group. A change is sought in the mix of the one-dimensional viewpoint of issues and the amelioration of economic/materialistic consumption through the operation of social relationships by taking into consideration the value dimension of human relationships. What is being sought is a symmetrical organizational structure, and as far as possible balanced coexistence of the material and value elements that constitute social normality, in synergy and not in competition. Even more so the matter at hand is the detachment from the pathogenesis of individualistic attitudes and behaviours, oriented towards ever-lasting social solidarity and expanded collective processes.

This constitutes the new view/challenge for social policy, where the desired readjustment in order to serve its purpose, passes through the awakening of social relationships, the values that constitute them and the operation of the value system. It has become clear that the pluralistic doctrine of social policy implementation, by utilizing all the resources, should indeed include the genuine implementation of social values and not only in semblance. As already pointed out, the system of social principles and values exists as a structural element of the models and the subsystems of sociopolitical intervention. Their importance is invaluable to individuals and society alike as models of collective interreactions and they constitute the link between the political, economic, social and cultural subsystems.

What is really sought in regard to the modern relationship between social policy, principles and values is ultimately located in the search for links, the synergy of the relationship from the individual to the person", from the "common" to the "society of persons" [4, p. 119]. Updating the concept of

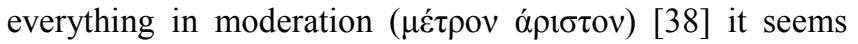
now the greatest challenge for the practical application of social principles and values in the social life.

\section{REFERENCES}

[1] Pontifico Consiglio Della Giustiziae Della Pace (2010) Synopsis of the Social Teachings of the Church. Athens: Psychogios Publications. (in Greek)

9 With the word person we identify a relationship. Namely, the person cannot exist outside the relationship with others, cannot be interpreted as a detached individuality (the Greek word 'prosopo=face' comes from the words 'pros'=towards and 'ops'=eyes, frontal aspect, having the frontal aspect face someone or something). This therefore is the main vital difference between a person and an individual: it cannot exist outside the relationship with other people too [37, p.23].
[2] Triantafyllidis M (1998) Dictionary-Portal of the Greek Language. Available at:

http://www.greek-language.gr/greekLang/modern greek/ tools/lexica/triantafyllides/search.html?lq $=\% \mathrm{CE} \% \mathrm{~B} 1 \% \mathrm{CF} \% 8$ $1 \% \mathrm{CF} \% 87 \% \mathrm{CE} \% \mathrm{~B} 7 \& \mathrm{dq}$ (accessed on 20 October 2016). (in Greek)

[3] Iatridis D (1990) Planning Social Policy. Athens: Gutenberg Publications. (in Greek)

[4] Stasinopoulou O (2007) From the Individual to the Human Person - The Contribution of the Thoughts of the Fathers in the Transcendence of Social Policy Dilemmas. In: Magripli D (ed) Critical Approaches to the Orthodox Culture - Aspects of the Greek Example. Athens: Stamouli Publications, 111-136. (in Greek)

[5] Koffas S (2013) Trends and particularities of the socio-political pluralism in Greece and Germany: The effect of culture and mentality as factors of different thinking and action in the practice of the socio-political pluralistic model. In: Sünker H et.al (eds) Citizen Participation in Social Welfare, Social Policy and Community Involvement: Shaping trends and attitudes of social responsibility. Frankfurt am Main: Peter Lang Publications, 83-99

[6] Esping-Andersen G (1990) The three Worlds of Welfare Capitalism. New Jersey: Princeton University Press.

[7] Kluckhohn C (1951) Values and value orientations in the theory of action. In: Parsons Tand Shields EA (eds) Toward a General Theory of Action. Cambridge, MA: Harvard University Press, 388-433.

[8] Feather NT (1994) Attitudes towards high achievers and reactions to their fall: Theory and research toward tall poppies. In: Berkowitz L (ed) Advances in Experimental Social Psychology vol 26. New York: Academic Press, 1-73.

[9] Rokeach M (1973) The Nature of Human Values. New York: Free Press.

[10] Bernard MM, Maio GR and Olson JM (2003) The vulnerability of values to attack: Inoculation of values and value-relevant attitudes Personality and Social Psychology Bulletin 29, 63-75.

[11] Tsaousis D (1989) Practical Sociology Dictionary. Athens: Gutenberg Publications. (in Greek)

[12] Katsoulis S (2014) Is Solidarity always the "Weapon of the People". Available at: http://stavroskatsoulis.blogspot.com.cy/2014/09/blog-post.ht $\mathrm{ml}$ (accessed 4 November 2016). (in Greek)

[13] Fuchs HW, Lautmann R, Rammstedt O and Wienold H (1994) Lexikon der Soziologie. Opladen: Westdeutsche Verlag.

[14] Schoenig WL and Hoest R (1996) Sozialstaat wohin? Umbau, Abbau oder Ausbau der Sozialen Sicherung. Darmstadt: Wissenschaftliche Buchgesellschaft.

[15] Engelhardt W (1981) Selbstverantwortung Solidarität, Subsidiarität und andere Sinnstrukturen der industriellen Gesellschaft. In: Herder- Dorneich P (ed) Schriften des Vereins für Sozialpolitik - Gesellschaft für Wirtschafts- und Sozialwissenschaften, Dynamische Theorie der Sozialpolitik vol 123. Berlin: Duncker \& Humblot, 55-78.

[16] Robolis S, Bagavos H and Romanias G (2003) Demographic Developments and National Insurance in Greece. In: Venieris 
D and Papatheodorou C (eds) Social Policy in Greece: Challenges and Prospects. Athens: Ellinika Grammata Publications, 168-213. (in Greek

[17] Brück G (1976) Allgemeine Sozialpolitik. Köln: Bund-Verlag $\mathrm{GmbH}$.

[18] Frerich J (1996) Sozialpolitik. Das Sozialleistungssystem der Bundesrepublik Deutschland 2. München/Wien: Auflage.

[19] Panagiotopoulos P (2012) Hellenic Circle The Solidarity Principle. Available at: www.hellenic-circle.eu/sites/default/files/.../solidarity_princip le.doc (accessed on: 30.10.2016). (in Greek)

[20] Kriaras E (2003) Dictionary of Modern Greek. Athens: Ekdotiki Athinon Publications. (in Greek)

[21] Koffas S (2014) Health Policy and the Co-Perception of Personal Responsibility in the Neo-Liberal Model. Social Work vol 115. Athens, 25-40. (in Greek)

[22] Schmid J (1996) Wohlfartsstaaten im Vergleich. Stand, Perspektiven und Probleme der Organisation und Finanzierung von sozialen Sicherungssystemen in Europa. Opladen: Leske and Budrich Publications.

[23] Schmid J and Niketta R (1998) Wohlfartsstaat: Krise und Reform im Vergleich. Opladen: Leske and Budrich Publications.

[24] Raffaelli R (2017) Factsheets for the European Union-2016. Available at:

http://www.europarl.europa.eu/ftu/pdf/el/FTU_1.2.2.pdf (accessed on 11 Januar 2017). (in Greek)

[25] Mardas G., Valkanos E., (2005), Social Policy, theory and practice. Administration, economy, law, sociology, Athens, Papazisis Publications (In Greek)

[26] Leibfried S and Mau S (2008) Welfare States. Construction, Deconstruction, Reconstruction. What is Social Policy? London: Elgar Edward Publishing.
[27] Wintersberger $H$ and Evers A (eds) (1991) Shifts in the Welfare Mix. Frankfurt: Campus Publications.

[28] Stasinopoulou O (1999) Issues of Modern Social Policy. From Welfare State to New Welfare Pluralism. Care and Ageing. The Modern Pluralistic Challenge. Athens: Gutenberg Publications. (in Greek)

[29] Koffas S (2009) Sozialpolitik in Deutschland und Griechenland. Eine Vergleichsuntersuchung zu ausgewahlten Bereichen in Rahmen der EU-Sozialordnung. Eichstatt: Diritto Publications (in German)

[30] Lampert $H$ and Althammer J (2001) Lehrbuch der Sozialpolitik 6th ed. Berlin: Springer Verlag.

[31] Zaimakis G (2002) Community Work and Local Communities. Development, Collective Action, Multi-Culturalism. Athens: Ellinika Grammata Publications. (in Greek)

[32] Stathopoulos P (1999) Social Welfare. A general view. Athens: Ellin Publications. (in Greek)

[33] Matsoukas N (1990) The future of Theology as Human science, Read, vol. 251, Athens, 30-36

[34] Matsaridis G (2007) Sociology of Christianity, Thessaloniki: P Pournara Publications. (in Greek)

[35] Koffas S (2011) Trends and specifications of the social policy in Greece and Germany. The cultural and mentality effect as a factor of a different thought and action over the practice of socio-political models, Athens, Journal of Social Work, vol. 104, Athens, 199-221

[36] Holloway J (2006) Change the World without Taking Power: The Meaning of Revolution Today. Athens: Savvalas Publications. (in Greek)

[37] Gioultsis V (2005) The "Other" Viewpoint of the Social. Thessaloniki: P Pournara Publications. (in Greek)

[38] Kleovoulos L., Wikipedia portal. Available at: https://el.wikipedia.org/wiki/\%CE\%9A $\% \mathrm{CE} \% \mathrm{BB} \% \mathrm{CE} \% \mathrm{~B} 5$ $\% \mathrm{CF} \% 8 \mathrm{C} \% \mathrm{CE} \% \mathrm{~B} 2 \% \mathrm{CE} \% \mathrm{BF} \% \mathrm{CF} \% 85 \% \mathrm{CE} \% \mathrm{BB} \% \mathrm{CE} \% \mathrm{BF}$ $\% \mathrm{CF} \% 82$ (accessed on 03 July 2017). (in Greek) 